\title{
The Level of Understanding, Appreciation and Practice among Malaysian Citizens from Education and Unity Perspective
}

\author{
Zamri Mahamod1, Nik Mohd Rahimi Nik Yusoff', Shamsuddin Othman², Alizah Lambri \\ ${ }^{1}$ Faculty of Education, Universiti Kebangsaan Malaysia, Bangi, Malaysia \\ ${ }^{2}$ Faculty of Education Studies, Universiti Putra Malaysia, Serdang, Malaysia \\ ${ }^{3}$ Faculty of Language and Communication, Universiti Pendidikan Sultan Idris, Tanjung Malim, Malaysia \\ Email: d-zam@ukm.edu.my
}

How to cite this paper: Mahamod, Z., Yusoff, N. M. R. N., Othman, S., \& Lambri, A. (2021). The Level of Understanding, Appreciation and Practice among Malaysian Citizens from Education and Unity Perspective. Creative Education, 12, 20742089.

https://doi.org/10.4236/ce.2021.129159

Received: August 2, 2021

Accepted: September 11, 2021

Published: September 14, 2021

Copyright ( 2021 by author(s) and Scientific Research Publishing Inc. This work is licensed under the Creative Commons Attribution International License (CC BY 4.0).

http://creativecommons.org/licenses/by/4.0/ (c) (i) Open Access

\begin{abstract}
This study aims to identify the level of understanding, appreciation and practice of identity among Malaysian citizens from education and unity perspective. Are Malaysians remained and still remain or begin to fade and fade understanding, appreciation and practice their Malay Language as an education and unity tools? Therefore, a survey was conducted on 1200 respondents of various races in Malaysia. The study respondents were randomly selected. The questionnaire was used as a data collection tool. The data were analyzed descriptively. The results showed that the overall level of understanding, appreciation and practice of Malay Language among Malaysians citizens from the perspective of education and unity still remains. In terms of race, the Malays show the level of understanding, appreciation and practice of Malay Language from the perspective of the eternal education and unity show. On the other hand, the Chinese, Indians, Sabah native, Sarawak native and other ethnic groups are still understanding. The implications of this study all the thought Malay Language is the best medium to foster racial in education and unity in Malaysia. All races still to understand, appreciate and practice Malay Language as a communication tool and instrument of unity among various races and ethnic in Malaysia.
\end{abstract}

\section{Keywords}

Level of Understanding, Level of Appreciation, Level of Practice, Unity, Malay Language

\section{Introduction}

Malay language is the Malaysia national language that serves as a platform to 
foster the spirit of love for the country. Through the national language, the spirit of nationalism and patriotism is sown, nurtured and strengthened (Abu Bakar, 2012). Malay language is a milestone for the country. In this case, Malay language will continue to be the mainstay of the nation, the pronunciation of culture and civilization that is able to assume and fulfill the agenda of the nation, and to deal with the changes and needs of society and the state. Peace, understanding, and unity that we have achieved so far is thanks to the success of the Malay language as the language of instruction in the education system as a national and official language of the country (Adam, 2005). Impossible to another language can take the place of Malay language as the unity and solidarity among multi-racial of Malaysian citizens. Nationalism must continue to be nurtured through the Malay language than other state emblems such as flags and symbols of statehood.

Malay language is a tool that can shape the national personality, and subsequently a tool that determines the progress of Malaysia (A'zmi et al., 2017). Therefore, without the use of Malay language as the national language, the country would face a variety of negative symptoms such as misunderstanding, racial prejudice, tension and crisis. Social and political stability is certainly difficult to achieve without a national language, because there is no single language that can act as a binding tool for soul and body. We need to realize that the strength of our nation's culture and can be built through the Malay language as a nation will be developed along with the progress of the language.

Malay language is the language most suited to bring together people of different races. The education aspect is the best platform in uniting these multi-racial among Malaysian citizens. Understanding, appreciation and practice of educational and unity identity through the use of one language, namely Malay language very important. The extent to which Malaysian citizens multi-racial understanding, appreciation and practice the use of the Malay language from the perspective of education and solidarity should be reviewed? Does the level of understanding, appreciation and practice of the Malay language they remained intact from the perspective of education and unity or fading? Therefore, this study aims to identify the multi-racial Malaysian citizens to understand, appreciate and practice education and unity perspective in terms of usage of Malay language.

\subsection{Statement of Problem}

The study of people's identity is not something new. Identity means to strengthen the community's confidence in the belief system that is adhered to by the community that adheres to the teachings of religion, does not do bad things (Bakar, 2010). The study of the identity of Malay language among Malaysia citizens of all races are less studied. Most studies to measure self-esteem involve more students of the Institute of Higher Education (refer to the study of Mahamod et al., 2017a, 2017b; Othman et al., 2012; Adam, 2005). The study of Yusof et al. (2015) in turn studied school students to see how strong they are in terms 
of their socioemotional identity. Review Musa (2008) and Karim \& Sarah (2015) was more useful to measure whether the Malays still strong identity or deviating Malay identity. Review them to identify whether the Malays has begun to fade their identity or vice versa. One aspect is Malay language factors other than religion, culture, education, unity, nationalism and so on.

Studies related to identity have been conducted by several researchers. For example, Adam (2005) study looks more at the extent to which Higher Education Institutions (HEI) students have an understanding, appreciation and practice of Pillars of the State (Rukun Negara). The findings of Adam study found that although significant, but there is already a leakage, reduction and fading of understanding, appreciation and practice of Rukun Negara among HEI students in Malaysia. Study by Othman et al. (2012) for example studied the national identity of HEI students. The findings of the study showed that 54.6 percent of HEI students have a strong sense of identity. The study of Othman et al. (2012) in general, that is, to all HEI students regardless of race. A study conducted by Musa (2008) also studies the Malay identity whether they still maintain their identities or had run their Malay identity. Results of the study found that many Malays are beginning to fade their identity in terms of value, but still remains the identity of the religion, science and students. Review Musa more to the Malays only, but a variety of categories. Studies done Karim \& Sarah (2015) using Musa (2008) also develop measurement tools Malay Hati Budi is online to determine the extent of the Malays still maintain the identity or otherwise. Review Sarah over to the Malays, but the number of respondents was too small not reflect the identity of the actual Malays.

Based on four studies, there is no one particular study examines the identity of education and unity among Malaysia citizens as measured through the use of Malay language. Therefore, there should be a study that specifically examines the identity of Malaysia citizens who see from the aspect of the identity of education and unity. This is important because in creating a united society, Malaysia citizens need to have a strong identity.

\subsection{Objective of Study}

This study aims to identify the identity of Malaysia citizens on the use of Malay language. Specifically, the objectives of this study are to:

1) Identify the identity of Malaysia citizens in terms of the understanding, appreciation and practice of Malay language based on education aspects.

2) Identify the identity of Malaysia citizens in terms of the understanding, appreciation and practice of the Malay language based on unity aspects.

\section{Methodology}

The design of this study was a survey using a quantitative approach. This study involves a large number of respondents. In this study, respondents were selected randomly aimed to get their views on the level of understanding, appreciation 
and practice of Malay language from the perspective of education and unity. For that, a total of 1200 respondents representing various races were used as the study sample. Simple random selection was more appropriate because the sample volunteered to answer the questionnaire. The number of respondents was set to represent a variety of categories such as gender, age, place of birth, occupation, level of mastery of the Malay language and so on. Determining the sample size makes it easier for researchers to conduct studies when the number of respondents is large and various categories (Piaw, 2014; Konting, 2005).

Therefore, the questionnaire instrument was used as a data collection tool. The questionnaire was constructed through past studies related to the researcher's study. In this study, the constructed questionnaire required respondents to answer according to a level scale using the Likert Scale which is divided into five categories. The Likert scale was chosen because it facilitates the collection of information about the degree of agreement of respondents to the items presented.

The constructed questionnaire consists of two main parts, namely Part A and Part $\mathrm{A}$ is the part to obtain information about the background of the respondents. Part B discusses the level of understanding, appreciation and practice of education and unity of identity with the use of Malay language. For the education aspect, there are 23 items, while for the unity aspect, there are 22 items.

The questionnaire used 10 Likert scales adapted and modified from the study of Mahamod et al. (2017a) and a study by the Malaysian Youth Development Research Institute, Ministry of Youth and Sports (2011). The Likert scale has a high level of reliability of up to 100 percent (Piaw, 2014). From the scale 1 to 10 , the scale is divided into 4 identity scales according to the Ministry of Youth and Sports (2011) as shown in Table 1.

The validity of the instrument is done with reference to three (3) appointed instrument evaluators. Cronbach alpha analysis (factor analysis) was performed using Statistical Package for Social Sciences (SPSS) software. As a result of the pilot study, the Cronbach alpha value obtained was 0.97 for the education aspect and 0.98 for the unity aspect. Cronbach's alpha values in excess of 0.6 are considered good items (Konting, 2005; Piaw, 2014). In this study, a total of 1200 respondents were selected to answer the questionnaire. Respondents were randomly selected consists of those working in the government sector, private sector, self-employment/business, ordinary people, students to get their views on Malay from the perspective of education and unity.

Table 1. Likert scale and category scale.

\begin{tabular}{ccc}
\hline Scale & Mean Scale & Category Scale \\
\hline $0-2$ & 1.00 till 2.99 & Fade \\
$3-5$ & 3.00 till 5.99 & Began to fade \\
$6-8$ & 6.00 till 8.99 & Still remains \\
$9-10$ & 9.00 till 10.00 & Remains \\
\hline
\end{tabular}


Data analysis in this study was made based on the instrument used, namely a questionnaire. The instruments of this study were analyzed using different approaches. After the relevant data were obtained, the authors then performed an analysis of the data. Quantitative data (questionnaires) were analyzed descriptively and inferentially using SPSS version 23. Descriptive statistical methods were used to describe the information or data obtained for the population and sample (Piaw, 2014). Descriptive statistics were also used to calculate the mean and standard deviation for each aspect studied. The mean score values for each construct were assessed based on the interpretation of the mean score by Ministry of Youth and Sports (2011) as shown in Table 1.

\section{Findings}

\subsection{Respondent Demographics}

The study involved 1200 citizens in various races, including Malay, Chinese, Indian, Thai, Punjabi, Sabah Native and Sarawak Native. A total of 200 respondents were randomly selected from each community to respond to the questionnaire provided. Of the total respondents, various age groups from 21 years to 60 years and above were involved in this study. Overall demographic information of the respondents is summarized in Table 2 according to percentage. Table 2 shows the data of study respondents based on the demographic characteristics of Malaysian citizens involved from the seven races in Malaysia research in Malaysia which are considered as variables in this study. For the gender variable, a total of 1200 respondents were sampled for the study who answered the questionnaire. The findings show that the gender distribution of the study respondents

Table 2. Respondent demographics.

\begin{tabular}{|c|c|c|c|c|}
\hline No. & & Category & Frequency (N) & Percentage (\%) \\
\hline \multirow{2}{*}{1} & \multirow{2}{*}{ Gender } & Male & 594 & 49.5 \\
\hline & & Female & 606 & 50.5 \\
\hline \multirow{5}{*}{2} & \multirow{5}{*}{ Age } & 21 - 30 years & 499 & 41.6 \\
\hline & & 31 - 40 years & 367 & 30.6 \\
\hline & & $41-50$ years & 172 & 14.3 \\
\hline & & 51 - 60 years & 121 & 10.1 \\
\hline & & 61 years and above & 41 & 3.4 \\
\hline \multirow{7}{*}{3} & \multirow{7}{*}{ Ethnic } & Malays & 200 & 16.7 \\
\hline & & Chinese & 200 & 16.7 \\
\hline & & Indians & 200 & 16.7 \\
\hline & & Siamese & 200 & 16.7 \\
\hline & & Punjabi & 200 & 16.7 \\
\hline & & Sabah native & 90 & 7.4 \\
\hline & & Sarawak native & 110 & 9.1 \\
\hline
\end{tabular}


consisted of 594 male respondents and 606 female respondents. This indicates that female respondents have a higher percentage than male respondents.

\subsection{Level of Identity Malaysia Citizens in the Aspect of Understanding, Appreciation and Practice of Malay Language from the Perspective Education}

This section discusses the level of identity of 1200 people from various races in Malaysia and various different backgrounds. The identity of the educator is discussed in three aspects, namely understanding, appreciation and practice. The extent to which all people involved is still or fading of identity in terms of the understanding, appreciation and practice of education with elements associated with the use of Malay language.

\subsubsection{Identity of Education: Understanding Aspect}

A total of eight items to measure the level of understanding of identity in education from Malay language perspective. Based on Table 3, the overall mean of the understanding of educational identity is 9.32 , which is at a high level or permanent identity. The average mean value ranged from mean 9.02 (item 8 ) to mean 9.83 (item 5). This means all the equipment to maintain their identity in terms of the use of Malay language in education.

Their understanding of the educational aspect is very high. They understand that the use of Malay language as the medium of education is necessary and

Table 3. Identity mean in education from understanding with use Malay language.

\begin{tabular}{|c|c|c|c|c|c|c|}
\hline \multirow[b]{2}{*}{ Understanding in Education } & \multicolumn{4}{|c|}{ Scale (Frequency) } & \multirow[b]{2}{*}{ Mean } & \multirow{2}{*}{$\begin{array}{l}\text { Level of } \\
\text { Means }\end{array}$} \\
\hline & $\begin{array}{c}\text { Fade } \\
(1-2)\end{array}$ & $\begin{array}{l}\text { Began to Fade } \\
(3-5)\end{array}$ & $\begin{array}{l}\text { Still Remain } \\
\quad(6-8)\end{array}$ & $\begin{array}{l}\text { Remain } \\
(9-10)\end{array}$ & & \\
\hline $\begin{array}{l}\text { 1) Know that Malay language is the official language in the } \\
\text { education system. }\end{array}$ & - & $\begin{array}{l}1.6 \% \\
(16)\end{array}$ & $\begin{array}{c}70.0 \% \\
(700)\end{array}$ & $\begin{array}{l}48.4 .0 \% \\
(484)\end{array}$ & 9.33 & Remain \\
\hline 3) Know when teacher speaks in Malay language. & - & $\begin{array}{l}0.9 \% \\
(9)\end{array}$ & $\begin{array}{c}19.8 \% \\
(198)\end{array}$ & $\begin{array}{c}99.3 \% \\
(993)\end{array}$ & 9.68 & Remain \\
\hline $\begin{array}{l}\text { 4) Know that Malay Language subject must pass in Malaysian } \\
\text { Certificate Education. }\end{array}$ & - & $\begin{array}{c}0.8 \% \\
(8)\end{array}$ & $\begin{array}{c}53.6 \% \\
(536)\end{array}$ & $\begin{array}{c}66.2 \% \\
(662)\end{array}$ & 9.43 & Remain \\
\hline $\begin{array}{l}\text { 6) Know that Malay language is the official language to } \\
\text { communication among ethnic in Malaysia. }\end{array}$ & $\begin{array}{c}0.9 \% \\
(9)\end{array}$ & $\begin{array}{c}130.0 \% \\
(130)\end{array}$ & $\begin{array}{c}27.0 \% \\
(270)\end{array}$ & $\begin{array}{c}79.1 \% \\
(791)\end{array}$ & 9.06 & Remain \\
\hline 7) Know that Malay language used in all national school. & - & $\begin{array}{c}0.3 \% \\
(3)\end{array}$ & $\begin{array}{l}57.2 \% \\
(572)\end{array}$ & $\begin{array}{c}62.5 \% \\
(625)\end{array}$ & 9.23 & Remain \\
\hline $\begin{array}{l}\text { 8) Know when friends describe a information in Malay } \\
\text { language. }\end{array}$ & & $\begin{array}{c}0.8 \% \\
(8)\end{array}$ & $\begin{array}{c}70.2 \% \\
(702)\end{array}$ & $\begin{array}{l}4.90 \% \\
(490)\end{array}$ & 9.02 & Remain \\
\hline \multicolumn{5}{|c|}{ Overall Mean-Understanding Aspect } & 9.32 & $\begin{array}{l}\text { Remain } \\
\text { Identity }\end{array}$ \\
\hline
\end{tabular}


appropriate to the status of the Malay language as the official language and the language of the country of Malaysia. For that reason, they understand the purpose of the use of the Malay language as the language of science in the context of education in Malaysia. Based on Table 3, it can be concluded that Malaysia citizens need to:

1) Respect the education system in Malaysia.

2) Understand that every education done is for the good of all parties.

3) Understand that education teaches its people to be united in all aspects of life.

4) Understand that the Malay language in education now needs to be applied.

5) Understand that education is the basis of life of various races and their rights must be respected in order to get free education.

\subsubsection{Identity of Education: Appreciation Aspect}

Referring to Table 4, a total of 8 items that measure the level of appreciation of educational identity. Of the 1200 multiracial people, more than $80 \%$ agree that they value education as part of their identity. They believe that the appreciation of education allows them to be good citizens and understand the use of the Malay language in education. The overall mean is at a high level, which is 9.11 . The average mean is between 8.39 (item 12) to 9.66 (item 10). This means that each race has a high level of appreciation of education when using Malay language.

The appreciation of higher education is the foundation of being a citizen with

Table 4. Identity mean in education from appreciation with use Malay language.

\begin{tabular}{|c|c|c|c|c|c|c|}
\hline \multirow[b]{2}{*}{ Appreciation in Education } & \multicolumn{4}{|c|}{ Scale (Frequency) } & \multirow[b]{2}{*}{ Mean } & \multirow{2}{*}{$\begin{array}{l}\text { Level of } \\
\text { Means }\end{array}$} \\
\hline & $\begin{array}{c}\text { Fade } \\
(1-2)\end{array}$ & $\begin{array}{l}\text { Began to Fade } \\
(3-5)\end{array}$ & $\begin{array}{l}\text { Still Remain } \\
\quad(6-8)\end{array}$ & $\begin{array}{l}\text { Remain } \\
(9-10)\end{array}$ & & \\
\hline $\begin{array}{l}\text { 9) More comfortable reading Malay language books } \\
\text { compared English/others language. }\end{array}$ & $\begin{array}{l}0.7 \% \\
(7)\end{array}$ & $\begin{array}{l}4.3 \% \\
(43)\end{array}$ & $\begin{array}{c}70.8 \% \\
(708)\end{array}$ & $\begin{array}{l}44.2 \% \\
(442)\end{array}$ & 9.34 & Remain \\
\hline $\begin{array}{l}\text { 11) More comfortable speaking with teacher using Malay } \\
\text { language compared others language. }\end{array}$ & - & $\begin{array}{l}0.3 \% \\
(3)\end{array}$ & $\begin{array}{c}60.6 \% \\
(606)\end{array}$ & $\begin{array}{l}59.1 \% \\
(591)\end{array}$ & 9.56 & Remain \\
\hline $\begin{array}{l}\text { 12) Like for information using the Malay language words } \\
\text { compared the English words/others language. }\end{array}$ & - & $\begin{array}{c}26.0 \% \\
(26)\end{array}$ & $\begin{array}{l}70.4 \% \\
(704)\end{array}$ & $\begin{array}{l}47.0 \% \\
(470)\end{array}$ & 8.39 & $\begin{array}{c}\text { Still } \\
\text { Remain }\end{array}$ \\
\hline $\begin{array}{l}\text { 14) Like prefer Malay language to write compared write } \\
\text { others language. }\end{array}$ & - & $\begin{array}{c}8.9 \% \\
(89)\end{array}$ & $\begin{array}{c}54.5 \% \\
(75)\end{array}$ & $\begin{array}{c}56.6 \% \\
(566)\end{array}$ & 8.75 & $\begin{array}{c}\text { Still } \\
\text { Remain }\end{array}$ \\
\hline 15) Like reading Malay language compared others language. & $\begin{array}{c}0.2 \% \\
(2)\end{array}$ & $\begin{array}{c}0.9 \% \\
(9)\end{array}$ & $\begin{array}{c}60.3 \% \\
(603)\end{array}$ & $\begin{array}{c}58.4 \% \\
(816)\end{array}$ & 8.92 & $\begin{array}{c}\text { Still } \\
\text { Remain }\end{array}$ \\
\hline $\begin{array}{l}\text { 16) Like prefer to read Malay language if there is bilingual } \\
\text { reading material. }\end{array}$ & $\begin{array}{c}0.7 \% \\
(9)\end{array}$ & $\begin{array}{c}0.9 \% \\
(9)\end{array}$ & $\begin{array}{c}59.0 \% \\
(590)\end{array}$ & $\begin{array}{c}59.2 \% \\
(592)\end{array}$ & 9.48 & Remain \\
\hline \multicolumn{5}{|c|}{ Overall Mean-Appreciation Aspect } & 9.11 & $\begin{array}{l}\text { Remain } \\
\text { Identity }\end{array}$ \\
\hline
\end{tabular}


a good identity. Therefore, the use of Malay language in the context of education is necessary for Malaysia citizens of all races. By reading Malay language books, looking for something in Malay language, like to read literature in Malay language and so are some of the ways used by Malaysian citizens in appreciating the role and status of Malay language as the official language in education. In summary, all Malaysia citizen needs:

1) Appreciating education can help every race succeed.

2) Respect educational institutions as a place to study.

3) Grateful for education as the best medium.

4) Believing that education can shape useful human beings.

5) Believing that education can provide well-being.

6) Respect educational institutions is obligatory for every human being.

7) Practice and appreciate every noble value in education.

\subsubsection{Identity of Education: Practice Aspect}

Table 5 presents the identity of Malay language among Malaysia citizens in terms of educational practice. A total of 6 items in evaluating the educational practices of citizens in various races. Data analysis showed that the overall mean was 8.79 , which is at the level of still remaining their identity. The mean is between 8.62 (item 17) to 8.93 (item 18). This means that the practice of Malay language in education by all ethnic groups in Malaysia began to decrease, but remains at the level of their identity. They still practice the Malay language in education. In summary, Malaysia citizens still practice (use) Malay language way:

1) Using Malay language to find reading material on the website.

2) Using keywords Malay language to find information.

3) Using Malay language to communicate with friends and teachers at school.

Table 5. Identity mean in education from practice with use Malay language.

\begin{tabular}{|c|c|c|c|c|c|c|}
\hline \multirow[b]{2}{*}{ Practice in Education } & \multicolumn{4}{|c|}{ Scale (Frequency) } & \multirow[b]{2}{*}{ Mean } & \multirow{2}{*}{$\begin{array}{l}\text { Level of } \\
\text { Means }\end{array}$} \\
\hline & $\begin{array}{l}\text { Fade } \\
(1-2)\end{array}$ & $\begin{array}{l}\text { Began to Fade } \\
\quad(3-5)\end{array}$ & $\begin{array}{l}\text { Still Remain } \\
\quad(6-8)\end{array}$ & $\begin{array}{l}\text { Remain } \\
(9-10)\end{array}$ & & \\
\hline $\begin{array}{l}\text { 17) Use Malay language ti find reading material on the } \\
\text { website. }\end{array}$ & $\begin{array}{c}1.0 \% \\
(10)\end{array}$ & $\begin{array}{l}10.5 \% \\
(105)\end{array}$ & $\begin{array}{l}42.7 \% \\
(427)\end{array}$ & $\begin{array}{c}65.8 \% \\
(658)\end{array}$ & 8.62 & $\begin{array}{c}\text { Still } \\
\text { Remain }\end{array}$ \\
\hline 18) Use keywords Malay language to find more information. & $\begin{array}{c}0.3 \% \\
(3)\end{array}$ & $\begin{array}{c}4.6 \% \\
(46)\end{array}$ & $\begin{array}{c}66.2 \% \\
(662)\end{array}$ & $\begin{array}{l}48.9 \% \\
(489)\end{array}$ & 8.93 & $\begin{array}{c}\text { Still } \\
\text { Remain }\end{array}$ \\
\hline 19) Use Malay language to talk with friend at school. & $\begin{array}{c}0.3 \% \\
(3)\end{array}$ & $\begin{array}{c}7.8 \% \\
(78)\end{array}$ & $\begin{array}{l}78.1 \% \\
(781)\end{array}$ & $\begin{array}{c}33.8 \% \\
(338)\end{array}$ & 8.65 & $\begin{array}{c}\text { Still } \\
\text { Remain }\end{array}$ \\
\hline 20) Use Malay language to communication with teacher. & - & $\begin{array}{l}9.7 \% \\
(97)\end{array}$ & $\begin{array}{c}66.3 \% \\
(663)\end{array}$ & $\begin{array}{l}44.0 \% \\
(440)\end{array}$ & 8.91 & $\begin{array}{c}\text { Still } \\
\text { Remain }\end{array}$ \\
\hline $\begin{array}{l}\text { 21) Like reading Malay language books compared reading } \\
\text { English books/others language. }\end{array}$ & $\begin{array}{c}0.3 \% \\
(3)\end{array}$ & $\begin{array}{c}9.8 \% \\
(98)\end{array}$ & $\begin{array}{l}56.0 \% \\
(560)\end{array}$ & $\begin{array}{c}53.9 \% \\
(539)\end{array}$ & 8.76 & $\begin{array}{c}\text { Still } \\
\text { Remain }\end{array}$ \\
\hline 22) Malay language is my favorite language at school. & $\begin{array}{l}1.6 \% \\
(16)\end{array}$ & $\begin{array}{l}9.2 \% \\
(92)\end{array}$ & $\begin{array}{l}39.3 \% \\
(393)\end{array}$ & $\begin{array}{l}69.9 \% \\
(699)\end{array}$ & 8.87 & $\begin{array}{c}\text { Still } \\
\text { Remain }\end{array}$ \\
\hline \multicolumn{5}{|c|}{ Overall Mean-Practice Aspect } & 8.79 & $\begin{array}{l}\text { Still Remain } \\
\text { Identity }\end{array}$ \\
\hline
\end{tabular}




\subsection{Level of Identity Malaysia Citizens in the Aspect of Understanding, Appreciation and Practice of Malay Language from the Perspective Unity}

The identity of unity in this study means that all races have a good and extensive knowledge of racial unity in Malaysia. To ensure racial unity is understood, appreciated and practiced, Malay used as an instrument of solidarity. Therefore, good cohesion and can help each race being a good citizen and united by a common language used, namely Malay language. The identity of unity is discussed in three aspects, namely understanding, appreciation and practice. How well each race is still or fading of identity in terms of the understanding, appreciation and practice of the Malay language as a tool of unity discussed in this section.

\subsubsection{Identity of Unity: Understanding Aspect}

In terms of the understanding of Malaysia citizens about the identity of unity shows a high mean, which is 9.31 (refer to Table 6). The mean value ranged from mean 8.99 (item 2) to mean 9.76 (item 4). All mean values are at the permanent level of identity. This means that every race in Malaysia understands that by having a good and broad sense of unity, then they become good citizens. They understand that unity can be conducted through Malay language. In other words, Malaysia citizens retain their identity of unity with every race. Malay language as a unity can be understood by the people of Malaysia. Each race also understands that by having and appreciating good unity, then they can:

Table 6. Identity mean in unity from understanding with use Malay language.

\begin{tabular}{|c|c|c|c|c|c|c|}
\hline \multirow[b]{2}{*}{ Understanding in Unity } & \multicolumn{4}{|c|}{ Scale (Frequency) } & \multirow[b]{2}{*}{ Mean } & \multirow{2}{*}{$\begin{array}{l}\text { Level of } \\
\text { Means }\end{array}$} \\
\hline & $\begin{array}{l}\text { Fade } \\
(1-2)\end{array}$ & $\begin{array}{l}\text { Began to Fade } \\
\quad(3-5)\end{array}$ & $\begin{array}{l}\text { Still Remain } \\
\quad(6-8)\end{array}$ & $\begin{array}{l}\text { Remain } \\
(9-10)\end{array}$ & & \\
\hline $\begin{array}{l}\text { 1) Know that Malay language can facilitate communication } \\
\text { between different ethnic and community. }\end{array}$ & $\begin{array}{l}0.3 \% \\
(3)\end{array}$ & $\begin{array}{c}0.9 \% \\
(9)\end{array}$ & $\begin{array}{l}412 \% \\
(412)\end{array}$ & $\begin{array}{c}77.6 \% \\
(776)\end{array}$ & 9.03 & Remain \\
\hline $\begin{array}{l}\text { 2) Know that Malay language can strengthen the relationship } \\
\text { between different ethnic and nation. }\end{array}$ & $\begin{array}{c}0.8 \% \\
(8)\end{array}$ & $\begin{array}{l}11.0 \% \\
(110)\end{array}$ & $\begin{array}{l}67.0 \% \\
(670)\end{array}$ & $\begin{array}{l}41.2 \% \\
(412)\end{array}$ & 8.99 & $\begin{array}{c}\text { Still } \\
\text { Remain }\end{array}$ \\
\hline $\begin{array}{l}\text { 3) Know that Malay language can create unity among the } \\
\text { local community. }\end{array}$ & - & $\begin{array}{l}0.1 \% \\
(1)\end{array}$ & $\begin{array}{l}22.2 \% \\
(222)\end{array}$ & $\begin{array}{c}97.7 \% \\
(917)\end{array}$ & 9.64 & Remain \\
\hline $\begin{array}{l}\text { 4) Know that meaning of the national song lyrics in Malay } \\
\text { language. }\end{array}$ & - & $\begin{array}{c}0.2 \% \\
(2)\end{array}$ & $\begin{array}{c}50.3 \% \\
(503)\end{array}$ & $\begin{array}{c}69.5 \% \\
(695)\end{array}$ & 9.76 & Remain \\
\hline $\begin{array}{l}\text { 5) Know that meaning of color and national flag in Malay } \\
\text { language. }\end{array}$ & - & $\begin{array}{l}0.4 \% \\
(4)\end{array}$ & $\begin{array}{l}43.9 \% \\
(439)\end{array}$ & $\begin{array}{c}75.7 \% \\
(757)\end{array}$ & 9.32 & Remain \\
\hline $\begin{array}{l}\text { 6) Know that meaning of five pillars of the state in Malay } \\
\text { language. }\end{array}$ & $\begin{array}{l}0.3 \% \\
(3)\end{array}$ & $\begin{array}{l}1.0 \% \\
(10)\end{array}$ & $\begin{array}{c}60.6 \% \\
(606)\end{array}$ & $\begin{array}{c}58.1 \% \\
(581)\end{array}$ & 9.08 & Remain \\
\hline $\begin{array}{l}\text { 7) Know the strong identity can create unity through Malay } \\
\text { language. }\end{array}$ & - & $\begin{array}{c}0.9 \% \\
(9)\end{array}$ & $\begin{array}{l}12.0 \% \\
(120)\end{array}$ & $\begin{array}{l}107.1 \% \\
(1071)\end{array}$ & 9.38 & Remain \\
\hline \multicolumn{5}{|c|}{ Overall Mean-Understanding Aspect } & 9.31 & $\begin{array}{l}\text { Remain } \\
\text { Identity }\end{array}$ \\
\hline
\end{tabular}


1) Understand that only a Malay language who can unite Malaysia citizens of all races.

2) Discharge their responsibilities as citizens obedient to the country and to respect the Malay language as the official language of the country.

3) Understand that unity is necessary to unite races through one language.

4) Understand that Malay language it can be done in various ways to unite the races in Malaysia.

5) Understand and acknowledge that the importance of regional Malay language is to be used.

6) Understand that unity can be controlled and utilized in life using Malay language.

7) Understand that the progress of a country depends a lot on its people who practice unity and mutual respect.

\subsubsection{Identity of Unity: Appreciation Aspect}

Table 7 discusses identity mean Malay language Malaysia citizens in terms of the appreciation of the unity that dominated them. The overall mean of knowledge identity is 9.41. The lowest mean for item 8 (mean 9.31) and the highest for item 11 (mean 9.52). All items in the appreciation of this knowledge are at the permanent level of identity. This means that Malaysians of various races remain their identities.

Malaysians of all races appreciate that knowledge is mastered to be used in their lives. Knowledge that is controlled can be obtained through the Malay language as well. By using Malay language only, Malaysians of all races can:

1) Appreciating that only a Malay language who can unite Malaysians of all races.

2) Every knowledge that is mastered must be lived in every activity.

Table 7. Identity mean in unity from appreciation with use Malay language.

\begin{tabular}{|c|c|c|c|c|c|c|}
\hline \multirow[b]{2}{*}{ Appreciation in Unity } & \multicolumn{4}{|c|}{ Scale (Frequency) } & \multirow[b]{2}{*}{ Mean } & \multirow{2}{*}{$\begin{array}{c}\text { Level of } \\
\text { Means }\end{array}$} \\
\hline & $\begin{array}{l}\text { Fade } \\
(1-2)\end{array}$ & $\begin{array}{c}\text { Began to Fade } \\
(3-5)\end{array}$ & $\begin{array}{l}\text { Still Remain } \\
\qquad(6-8)\end{array}$ & $\begin{array}{l}\text { Remain } \\
(9-10)\end{array}$ & & \\
\hline $\begin{array}{l}\text { 8) Realize that learn the identity of Malaysia in Malay } \\
\text { language can build a spirit of the homeland. }\end{array}$ & - & $\begin{array}{l}0.2 \% \\
(2)\end{array}$ & $\begin{array}{l}37.8 \% \\
(378)\end{array}$ & $\begin{array}{l}82.0 \% \\
(820)\end{array}$ & 9.31 & Remain \\
\hline $\begin{array}{l}\text { 9) Believes that embrace the principles of pillars the state in } \\
\text { Malay language can add love the country. }\end{array}$ & - & $\begin{array}{c}0.6 \% \\
(6)\end{array}$ & $\begin{array}{c}76.5 \% \\
(765)\end{array}$ & $\begin{array}{l}42.9 \% \\
(429)\end{array}$ & 9.50 & $\begin{array}{c}\text { Still } \\
\text { Remain }\end{array}$ \\
\hline $\begin{array}{l}\text { 10) Believes that schools using Malay language as the } \\
\text { language of instruction will foster unity among students. }\end{array}$ & - & $\begin{array}{r}4.0 \% \\
(40)\end{array}$ & $\begin{array}{l}46.3 \% \\
(463)\end{array}$ & $\begin{array}{c}69.7 \% \\
(697)\end{array}$ & 9.34 & Remain \\
\hline $\begin{array}{l}\text { 11) Realize that living with people who are fluent in Malay } \\
\text { language can create a harmonies society. }\end{array}$ & - & $\begin{array}{c}2.2 \% \\
(22)\end{array}$ & $\begin{array}{l}46.3 \% \\
(463)\end{array}$ & $\begin{array}{r}71.5 \% \\
(715)\end{array}$ & 9.52 & Remain \\
\hline $\begin{array}{l}\text { 12) Using of the Malay language in neighborhoods with a } \\
\text { variety race. }\end{array}$ & - & $\begin{array}{l}0.3 \% \\
(3)\end{array}$ & $\begin{array}{l}82.3 \% \\
(823)\end{array}$ & $\begin{array}{c}37.4 \% \\
(374)\end{array}$ & 9.44 & Remain \\
\hline \multicolumn{5}{|c|}{ Overall Mean-Appreciation Aspect } & 9.41 & $\begin{array}{l}\text { Remain } \\
\text { Identity }\end{array}$ \\
\hline
\end{tabular}


3) Appreciate and believe that the unity that is mastered can make them good citizens and respect each other.

4) Appreciate that unity can occur and be deepened in various ways.

5) Believing that with mastered unity can increase their knowledge.

6) Believes that unity can be obtained and achieved by using Malay language.

7) Believing that people who practice unity have a high value of life norms to succeed in life.

\subsubsection{Identity of Unity: Practice Aspect}

Table 8 presents the findings of an analysis of the identity of Malay language Malaysia citizens in terms of practice. A total of 10 items submitted to determine the identity of the practice of Malay language Malaysia citizens in terms of solidarity. The findings show that 1200 Malaysian people of various races retain their identity. The overall mean of the practice of unity identity is 9.21 , which is at the permanent level of identity. The average mean value ranged from mean 8.80 (item 20) to mean 9.45 (item 13). This means that each race remains their identity by adopting the use of the Malay language as a tool of unity in society.

In other words, unity can be fostered among Malaysian people through Malay

Table 8. Identity mean in unity from practice with use Malay language.

\begin{tabular}{|c|c|c|c|c|c|c|}
\hline \multirow[b]{2}{*}{ Practice in Unity } & \multicolumn{4}{|c|}{ Scale (Frequency) } & \multirow[b]{2}{*}{ Mean } & \multirow{2}{*}{$\begin{array}{l}\text { Level of } \\
\text { Means }\end{array}$} \\
\hline & $\begin{array}{c}\text { Fade } \\
(1-2)\end{array}$ & $\begin{array}{l}\text { Began to Fade } \\
(3-5)\end{array}$ & $\begin{array}{l}\text { Still Remain } \\
(6-8)\end{array}$ & $\begin{array}{l}\text { Remain } \\
(9-10)\end{array}$ & & \\
\hline $\begin{array}{l}\text { 13) Using Malay language during communication with } \\
\text { neighborhoods a different races. }\end{array}$ & - & $\begin{array}{l}0.2 \% \\
(2)\end{array}$ & $\begin{array}{c}23.7 \% \\
(237)\end{array}$ & $\begin{array}{l}96.1 \% \\
(961)\end{array}$ & 9.45 & Remain \\
\hline $\begin{array}{l}\text { 14) Using Malay language during communication with } \\
\text { neighborhoods same races. }\end{array}$ & - & $\begin{array}{c}0.9 \% \\
(9)\end{array}$ & $\begin{array}{c}66.1 \% \\
(661)\end{array}$ & $\begin{array}{l}53.0 \% \\
(53.0)\end{array}$ & 9.17 & Remain \\
\hline $\begin{array}{l}\text { 15) Using Malay language to solve the problem among } \\
\text { neighborhoods. }\end{array}$ & - & $\begin{array}{c}0.20 \% \\
(20)\end{array}$ & $\begin{array}{c}61.1 \% \\
(611)\end{array}$ & $\begin{array}{l}63.1 \% \\
(631)\end{array}$ & 9.25 & Remain \\
\hline $\begin{array}{l}\text { 16) Using Malay language in daily activities to show the } \\
\text { feeling of love for the homeland. }\end{array}$ & $\begin{array}{c}0.6 \% \\
(6)\end{array}$ & $\begin{array}{c}0.4 \% \\
(4)\end{array}$ & $\begin{array}{r}29.9 \% \\
(299)\end{array}$ & $\begin{array}{l}89.1 \% \\
(891)\end{array}$ & 9.24 & Remain \\
\hline 17) Using Malay language to closer my neighborhoods. & $\begin{array}{c}0.1 \% \\
(1)\end{array}$ & $\begin{array}{c}0.9 \% \\
(9)\end{array}$ & $\begin{array}{l}52.1 \% \\
(521)\end{array}$ & $\begin{array}{c}66.9 \% \\
(669)\end{array}$ & 9.18 & Remain \\
\hline $\begin{array}{l}\text { 18) Using Malay language when communication with my } \\
\text { family. }\end{array}$ & $\begin{array}{c}0.7 \% \\
(7)\end{array}$ & $\begin{array}{c}0.9 \% \\
(9)\end{array}$ & $\begin{array}{l}97.7 \% \\
(97.7)\end{array}$ & $\begin{array}{c}20.7 \% \\
(207)\end{array}$ & 9.37 & Remain \\
\hline 19) Spoken with someone unfamiliar with Malay language. & $\begin{array}{c}0.1 \% \\
(1)\end{array}$ & $\begin{array}{l}1.6 \% \\
(16)\end{array}$ & $\begin{array}{c}56.6 \% \\
(566)\end{array}$ & $\begin{array}{c}61.7 \% \\
(617)\end{array}$ & 9.21 & Remain \\
\hline 20) Using Malay language to learn identity of state. & $\begin{array}{l}0.9 \% \\
(9)\end{array}$ & $\begin{array}{r}9.9 \% \\
(99)\end{array}$ & $\begin{array}{c}37.2 \% \\
(372)\end{array}$ & $\begin{array}{l}72.0 \% \\
(720)\end{array}$ & 8.80 & $\begin{array}{c}\text { Still } \\
\text { Remain }\end{array}$ \\
\hline $\begin{array}{l}\text { 21) Using Malay language in daily activities to show the } \\
\text { feeling of love for the homeland. }\end{array}$ & $\begin{array}{l}0.9 \% \\
(9)\end{array}$ & $\begin{array}{l}10.3 \% \\
(103)\end{array}$ & $\begin{array}{c}56.2 \% \\
(562)\end{array}$ & $\begin{array}{l}52.6 \% \\
(526)\end{array}$ & 9.24 & Remain \\
\hline $\begin{array}{l}\text { 22) Using Malay language to appreciate principles of the } \\
\text { pillars of state. }\end{array}$ & $\begin{array}{c}0.1 \% \\
(1)\end{array}$ & $\begin{array}{r}2.3 \% \\
(23)\end{array}$ & $\begin{array}{l}48.9 \% \\
(489)\end{array}$ & $\begin{array}{c}58.8 \% \\
(588)\end{array}$ & 9.24 & Remain \\
\hline \multicolumn{5}{|c|}{ Overall Mean-Practice Aspect } & 9.21 & $\begin{array}{l}\text { Remain } \\
\text { Identity }\end{array}$ \\
\hline
\end{tabular}


language. Through the adoption of Malay language, solidarity can be fostered between the races in Malaysia. Therefore, each race should be:

1) Study and practice of unity in Malay language important to every citizen.

2) Practice all kinds of unity in daily activities and life.

3) Use the right medium of unity.

4) Using Malay language, communicate and interact with various communities to enhance relationships with each other.

5) Learn from those who are tolerant to practice the attitude of unity as the main basis for increasing unity.

\section{Discussion}

\subsection{Education Aspect}

The most important element or aspect to form an identity is education. Education is a "powerful weapon" to form an identity among them, let alone if its people consist of various races and ethnic groups like Malaysia. Therefore, education is a weapon for the Malaysia government to shape the identity and identity among its people. According to Mahamod (2017a), identity shapes a nation's identity. Therefore, education is the most important element in shaping the identity of a sovereign and dignified nation.

One of the important aspects or elements in building a strong identity of a nation is through the quality of knowledge possessed by the nation. The quality of knowledge is only obtained through the quality of education provided by the government. In the context of Malaysia, the Ministry of Education Malaysia (MOE) and the Ministry of Higher Education (MOHE) are the two government agencies responsible for providing quality education. MOE for primary and secondary schools, while KPT for higher education. To what extent have these two ministries succeeded in producing human resources that are permanent and their identity remains.

The findings of this study are in line with the study of Mahamod et al. (2020) which states that the level of understanding, appreciation and practice of the Malay language as a whole is high, including in education. In this study, Malaysians of all races to understand, appreciate and practice Malay language in an educational context. Malaysians of all races know that Malay language is the language of science used in all stages and levels of education. Only Malay language only suitable for use as the language of instruction for all levels of education, whether primary, secondary or tertiary. National education system who speak Malay medium is the best example of how to nurture Malaysia citizens united in terms of education.

Similarly, the study of Mahamod et al. (2017a) who found the level of understanding, appreciation and practice of the identity of Malay language among students of Public University education is still remained their identity. Although the study of Mahamod et al. (2017b) is among Public University students, but the students are multi-racial. This is also related to this study where among the 
study sample taken as study respondents are higher education students. In other words, self-education and the use of the Malay language as the language of science in the context of education is high. Malaysians of all races regardless of the status of education to understand, appreciate and practice Malay language in educational context.

Similarly, other studies that examined the use of Malay language as the language of education in Malaysia as a study by Othman et al. (2012), Yusoff and Thukimin (2009), Hoon and Mezah (2012) and other social researchers state that:

1) Malay language is very effective to use the language of education for Malaysians of all races.

2) Malay language in the context of education can foster a spirit of unity among Malaysians of all races.

3) Malay language can create goodwill among pupils and students when used as the language of instruction in schools.

In conclusion, Malaysia citizens need to have a strong identity. A strong identity can only be obtained through high quality education. Only the aspect of education can shape and build the identity of the people in a dignified country. National education system with the medium of Malay language is the best in nurturing the identity of Malaysians of all races. The same education received will strengthen the identity of Malaysians of various races. The existence of multi-stream schools brings more disadvantages to a country whose people are multiracial like Malaysia.

\subsection{Unity Aspect}

From the aspect of unity, the overall height of Malaysia citizens have high selfesteem to understand, appreciate and practice to use the identity of Malay unity. With a mean value of 9.31, which proves the eternal identity of Malaysia citizens using Malay language for the purpose of solidarity. The findings of this study are in line with a parallel study with the study of Yusoff and Thukimin (2009), Radzlan et al. (2012) and Singh (2013).

For example, the study of Yusoff and Thukimin (2009) who studied the role of language as a tool of social interaction of Malaysian citizens. The use of Malay language as a means of interaction between the various communities can foster a sense of unity among the races. Malay language is used as an instrument of solidarity. Malaysian citizens to understand, appreciate and practice Malay language for the purpose of solidarity. Malaysians know that one of the factors to maintain unity is through the national language. In the context of this study, it is clear that Malaysians understand, appreciate and practice the element of unity in their lives in this multi-racial country. In other words, Malay language is the national language of unity for multi-racial like Malaysia.

Similarly the study of Radzlan et al. (2012) who studied how social personality can create unity among multiracial Malaysia citizens. This social interaction is 
seen from the aspect of communication in various situations whether in formal or informal situations. This means that the aspect of racial unity can be strengthened through a language that all citizens understand. In the Malaysian context, it is clear Malay language works well as a language of communication, language, interaction and language of unity that unites every race and ethnicity in Malaysia.

Studies conducted by Adam (2005), Nasir and Ahmad (2009), Peng (2018), Othman et al. (2012), Awang et al. (2015) and others conclude that all Malaysia citizens to understand, appreciate and practice Malay language a language of unity. The researchers acknowledge that Malay language is the most effective in promoting and building the spirit of unity among races and ethnic groups in Malaysia. All researchers understand that the spirit of unity and mutual respect between ethnic groups in Malaysia can be achieved through a single language, namely Malay language. When all Malaysia citizens have common values, namely Malay language is owned by Malaysia citizens, then they will use Malay language for social purposes such as communicating and interacting.

The conclusion from this study is that the aspect of unity in Malaysia can be strengthened through one language. Malay language as the interaction among the various races in Malaysia can make the country peaceful and harmonious. Multiracial understanding, appreciating and practicing through a language that is understood, namely Malay language.

\section{Implication and Conclusion}

The study achieved the planned objectives. Malaysia citizens of various races and religions remain intact in terms of education and unity. Malaysia citizen remains understand, appreciate and practice self-esteem in their lives through the use of Malay language $\mathrm{n}$ education and unity. Malaysia citizens still understand that Malay language is the official language, national language and unity among Malaysia citizens as enshrined in Article 152 of the Federal Constitution of Malaysia. Malay language should be used in education and unity in particular aspects of identity such as the administrative aspects, economic, social, cultural, religious and other identities that remain intact in the hearts of Malaysia citizens. The implications of the study on the aspects of education and unity are:

1) Understand the importance of Malay language as a tool of unity in education among the various races in Malaysia. Malay language should be understood in the context of education. By understanding Malay language, Malaysia citizens can learn Malay language easily and quickly. Besides, Malaysia citizens to understanding of the importance of unity in education will help them trust and respect each other.

2) Appreciate the Malay language as a tool of unity in education among the various races in Malaysia. Malay language should be appreciated in the context of education and unity perspective. By embracing Malay language, Malaysia citizens can use Malay language correctly. Besides, appreciation of the use of the 
Malay language can be translated through communication and interaction each other. Therefore, national education system is the best platform to appreciate the status and position of the Malay language as the language of unity and national language.

3) Practice Malay language as effective communication in education perspective among the various races in Malaysia. Thus, the effective use of the Malay language as a means of communication and interaction can be used in education. Through the national education system, Malaysia citizens can learn and use proper Malay language when communicating and interacting with each other. Besides, Malay language should be practiced in the context of education and unity. By practicing Malay language, all Malaysia citizens are able to communicate with both the official and unofficial purposes through the use Malay language correctly.

\section{Acknowledgements}

Thanks to the Malaysia Ministry of High Education for providing the Fundamental Research Grant Scheme research code: FRGS/1/2018/SS109/UKM/01/1 till this article is successfully published.

\section{Conflicts of Interest}

The authors declare no conflicts of interest regarding the publication of this paper.

\section{References}

Abu Bakar, A.L. (2012). Identity and Patriotism Are Centered on History, Constitution and Government Policy. In Identity and Patriotism at the Core of Malaysian Civilization (pp. 1-34). Series of Research and Publication of Malay Civilization Institution, Universiti Pendidikan Sultan Idris.

Adam, R. (2005). The Study of Level Understanding, Appreciation and Practice Rukun Negara among Higher Education Institute Students. Research Grant, Jabatan Perpaduan Negara dan Integriti Nasional Press.

Awang, M. M., Rahman, A. A. A., Amin, N. M., \& Ahmad, A. R. (2015). Unity Message from Malay Language Text Books Form 4 and 5: Analysis of Malay Proverbs. Journal of Malay Language Education, 5, 44-52.

A'zmi, A. A., Mustafar, F. W., Abdul Karim, A. K., Mustafar, F. W., Abdul Karim, A. K., \& Suhaini, N. (2017). A Reality of Racial Diversity towards Post-Independence National Unity. Malaysian Journal of Social Science, 2, 1-24.

Bakar, I. (2010). History of Leadership and Politics towards the Formation of National Identiti. In M. Y. Othman et al., (Ed.). National Identity of Manhaj Islam Hadhari (pp. 197-120). Institut Islam Hadhari Press, Universiti Kebangsaan Malaysia.

Hoon, A. L., \& Mezah, C. R. (2012). Use Problem Malay Language among Chinese Ethnic Students in Malaysia. Journal of Sociahumanika, 5, 215-226.

Karim, S., \& Sarah, A. (2015). Development of Malay Identity Instrument. Doctoral Dissertation, Faculty of Modern Language and Communication, Universiti Putra Malaysia. 
Konting, M. M. (2005). Educational Research Method (5th ed.). Dewan Bahasa and Pustaka Press.

Mahamod, Z., Yuoff, N. M. R. N., Awang, M. M., \& Peng, C. F. (2017a). The Development of Identity Index among Students of Educational Streams at Malaysia Public Institute of Higher Education. Final Report of Grant: FRGS/1/2015/SS06/UKM/01/1, Malaysia Ministry of Higher Education.

Mahamod, Z., Yusoff, N. M. R. N., Awang, M. M., Bahari, U. T., \& Peng, C. F. (2017b). The Aspect of Understanding, Appreciation and Practice of Identity among Students of Education in Malaysian Public Universities. International Journal of Science Arts and Commerce, 2, 83-98.

Mahamod, Z., Yusoff, N. M. R. N., Othman, S., Lambri, A., \& Hassan, H. (2020). Level of Understanding, Appreciation and Practice Malay Language Identity among Malaysian Citizens. Journal of Malay Language Education, 10, 27-36.

Ministry of Youth and Sports. (2011). Malaysia Indexing Youth. Institut Penyelidikan dan Pembangunan Belia Malaysia Press.

Musa, H. (2008). Social Character Malay Trait: Strengthening the Challenge of the 21st Century. Universiti Putra Malaysia Press.

Nasir, Z. M., \& Ahmad, N. (2009). Social Development in Ethnic Relationship. In T. Kassim, \& A. R. Hamidah (Eds.), Ethnic Realtionship in Malaysia: Theory Perspective and Practice (pp. 141-154). Universiti Teknologi Malaysia Press.

Othman, M. Y., Dakir, J., Samian, A. L., Hasim, M. S., Awal, N. A. M., Yahya, S. A., Hanapi, R. M., Omar, N., \& Bakar, M. A. (2012). National Identity among Higher Education Institute Students. Journal Hadhari Special Edition, 67-78.

Peng, C. F. (2018). The Attitude of Chinese Students to Malay Language. The Asia Pasific Journal of Curriculum and Teaching, 6, 1-11.

Piaw, C. Y. (2014). Research Basic Statistic (2nd ed.). McGraw Hill (M) Inc.

Radzlan, R., Gill, S. S., \& Talib, A. T. (2012). Understanding and Practice Rukun Negara among Town Youth in Peninsular of Malaysia. Malaysia Journal of Youth Studies, 7, 55-65.

Singh, S. S. D. (2013). The Study of Understanding, Appreciation and Practice Rukun Negara among Malaysia Youth. Jurnal Perpaduan Institut Kajian dan Latihan Integrasi Nasional, 1, 89-137.

Yusof, R., Isha, N. M., \& Zahidi, A. M. (2015). Leadership Characteristic among Gifted and Talented Students at Malaysia National Gifted Center. International Journal of Scientific Research, 4, 588-593.

Yusoff, R. M., \& Thukimin, K. (2009). Theory and Thought on Ethnic Relationship. In T. Kassim, \& A. R. Hamidah (Eds.), Ethnic Realtionship in Malaysia: Theory Perspective and Practice (pp. 17-53). Universiti Teknologi Malaysia Press. 